(C) University of Lapland and Authors 2013

\section{Edited by}

Elina Härkönen

Timo Jokela

Ásthildur Jónsdóttir

\section{Graphic Design}

Elina Härkönen

\section{Cover image}

Vladimir Durnev

\section{Financier}

Nordic Council of Ministries

\section{Publisher}

University of Lapland; Rovaniemi 2013

Publications of the Faculty of Art and Design of the University of Lapland

Series C. Overviews and discussion 40

ISSN 1236-9616

www.ulapland.fi

ISBN 978-952-484-686-8

ISBN 978-952-484-687-5 (pdf) 


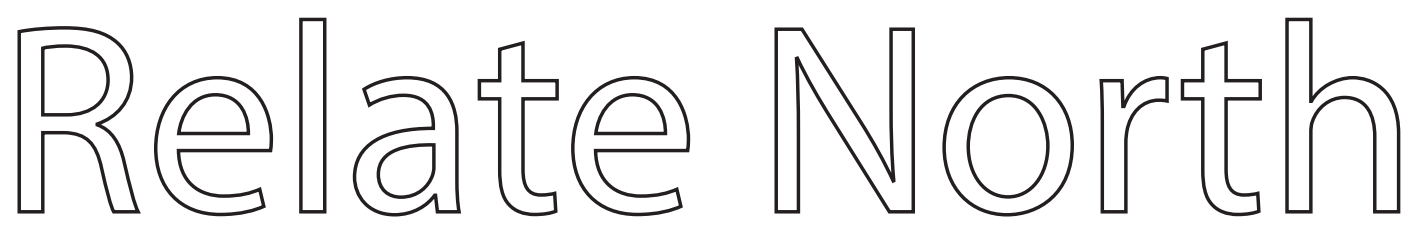

ENGAGEMENT, ART AND REPRESENTATION 2013

Exhibition in Nordic House, Reykjavik University of Lapland and Iceland Academy of Arts 8th - 24th Novermber 2013 



\section{Foreword}

Welcome to RELATE NORTH 2013 the second exhibit of the University of the Arctic's thematic network Arctic Sustainable Arts and Design (ASAD). The fundamental aim is to create a platform for safeguarding the sustainability of cultural diversity in the North and to support the local social and environmental development of local communities through sustainable means of art and art education.

Creating, experimenting and interpreting art is deeply personal and highly individual and only the viewer can choose to travel that path. The role of the curator in this exhibit is to create conditions for it, to showcase something truly worthwhile, capable of moving the viewer to wanting to understand oneself, to find their place in the world, to see and accept life.

This exhibition is about the visitors and for them. It shows that the world is big and everyone should have a place in it. As you walk through the exhibit and read the artist statements, you see works that touch upon ecological, environmental and philosophical themes connected to sustainability. The works deal with who we are, the world that surrounds us and how we act.
People know what they do; they frequently know why they do what they do; but what they don't know is what what they do does...

The work of an intellectual is not to mold the political will of others; it is, through the analyses of what he does in his own field, to re-examine evidence and assumptions, to shake up habitual ways of working and thinking, to dissipate conventional familiarities, to re-evaluate rules and institutions and to participate in the formation of a political will where he has his role as citizen to play. (Foucault)

The exhibition consists of perspectives from all the member countries of the ASAD network: Canada, Finland, Iceland, Norway, Russia, Scotland, Sweden and United States.

I hope the exhibition will help you to deepen your understanding of its topic; sustainability. Hopefully you will immerse yourself into it and ask yourself what you can do to find a balance between our complex ecology and well-being.

Reykjavík October 18th 2013 Ásthildur Jónsdóttir curator 


\section{Artists}

\author{
Kieran Meagher \\ Ásthildur Jónsdóttir \\ Kristín María Ingimarsdóttir \\ María Sjöfn Dupuis Davíðsdóttir \\ Svanborg Matthíasdóttir \\ Rósa Gísladóttir \\ Guðlaugur Valgarðsson \\ Lovísa Sigurðardóttir \\ Brynja Emilsdóttir \\ Marjo Pernu \\ Timo Jokela \& Mirja Hiltunen \\ Hilkka Kemppi \& Suvi Autio \\ Esther Dorsman
}

\author{
Anne-Kari Steiro Berg-Hanssen \\ Hilde Hauan Johnsen \\ Sol Moren \\ Ruth Beer \\ Katie Bethune-Leamen \\ Herminia Wei-Hsin Din \\ David Mollett \\ Vladimir Durnev \\ Irina Zemtsova \\ Tuiaara Shaposhnikova \\ Alan Paterson \\ Roxanne Permar \& Susan Timmins \\ Gina Wall
}

Mette Gårdvik, Karin Stoll \& Wenche Sørmo 


\section{Lost, towards Iceland}

\section{KIERAN MEAGHER}

Paint North. The work is a large triptych painting, oil on board: the panels, measuring 122 × $90 \mathrm{~cm}$ each. The triptych is of three views to sea from the most northerly county in Ireland, Donegal. The 'towards Iceland' paintings, all three made in one day, the board, working flat on the sand, I will work on all fours by the waters edge, the tide, the wind, the view, the immersion in a working process, the imagined place, the distance of Iceland, somewhere there, an imagined place - the far edge, lost.

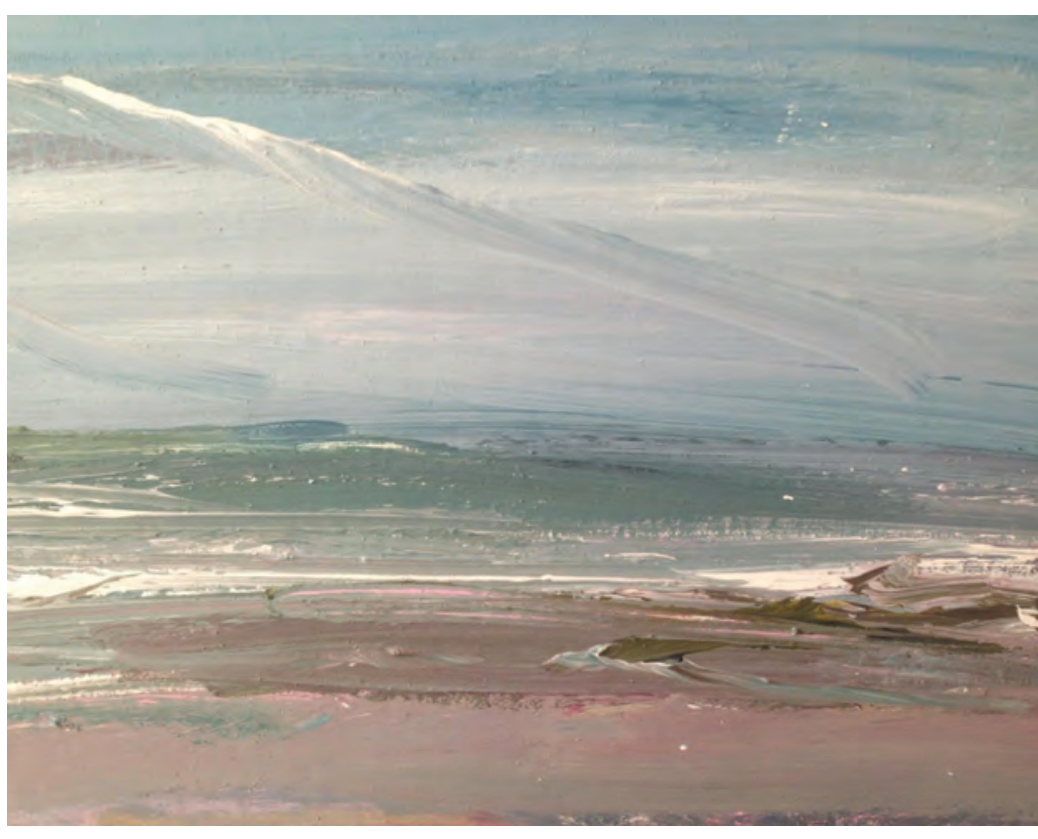

Oil on board: $3 \times 122 \times 90 \mathrm{~cm}$ 


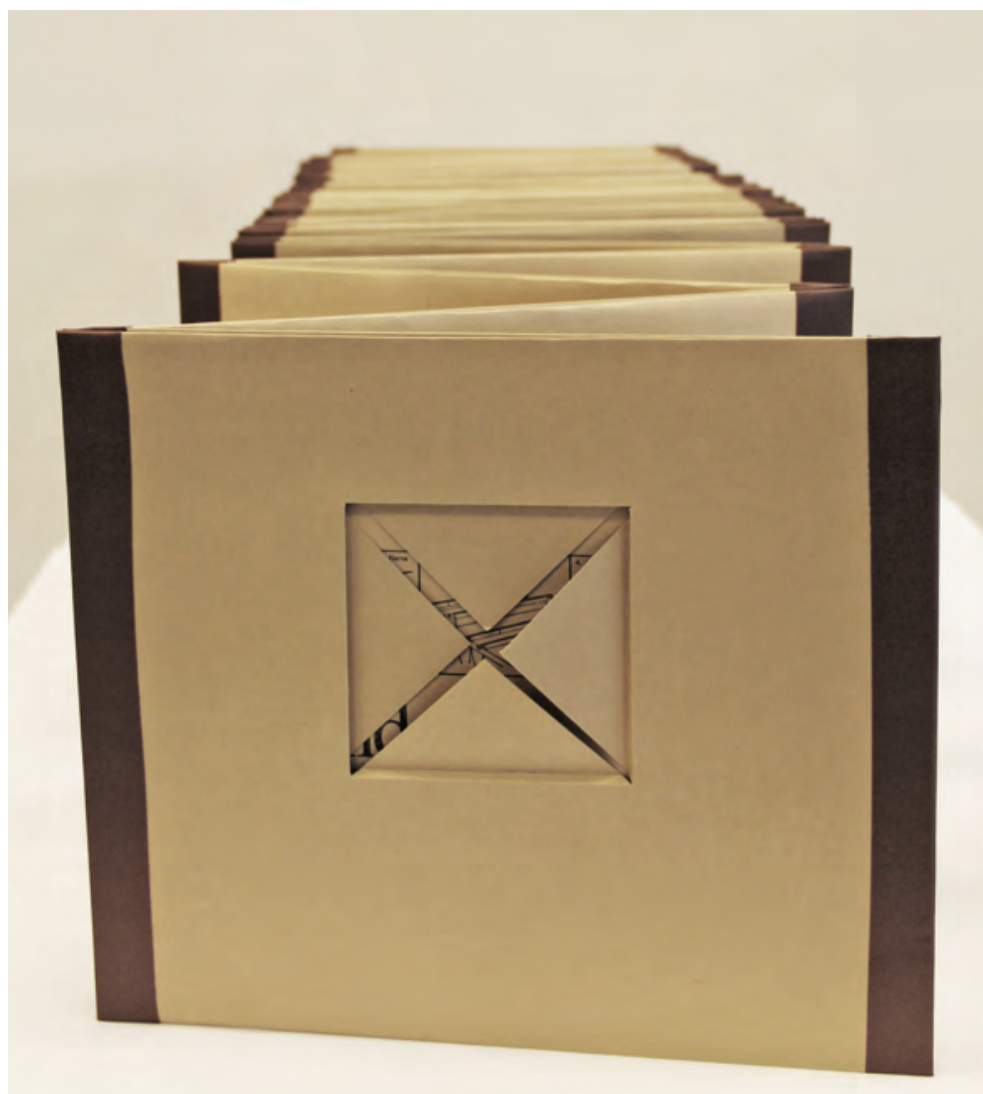

\title{
Value Archive
}

\author{
ÁSTHILDUR JÓNSDÓTTIR
}

This work stems with my interest in memory and values. Memories shape our current behavior and the way we perpetuate customs and traditions. Unconsciously, we classify, organize and memorialize events in our lives. At the end of every relationship, event, and experience, an individual is left with the memory. My memories are layered, sometimes they resurface and then they fade away. In this ongoing work I am seeking to create a space to remember the stories of friends and families. I believe that they create memories that are worth passing on to future generations. Their stories represent my own search for my intrinsic values. My work is of participatory origin, in that I have invited 43 people to share in the creation of a book based on messages they want to pass on to future generations. The number of participants represent my age.

Artbook 


\section{Hey}

\section{KRISTIIN MARÍA INGIMARSDÓTTIR}

"Hey“ is an installation; an animation projection on to a wall-piece, made with hay and baling twine. It is both a formal work based on the animation which is constructed from photos of new-grown grass in a field, dried hay and the connection between these elements. The work is also homage to my grandfather, who was a farmer and I was fortunate to grow up with him. He was concerned about recycling and did not like to waste good materials like these baling twines that were used to bind the bales of hay and usually got thrown away after feeding the hay to the animals.

My grandfather belonged to a generation who grew up with almost none of the modern technique and luxury we do take for granted today, lifestyle that makes our lives more confortable and easier in one way but also threatens our environment now and in the future.

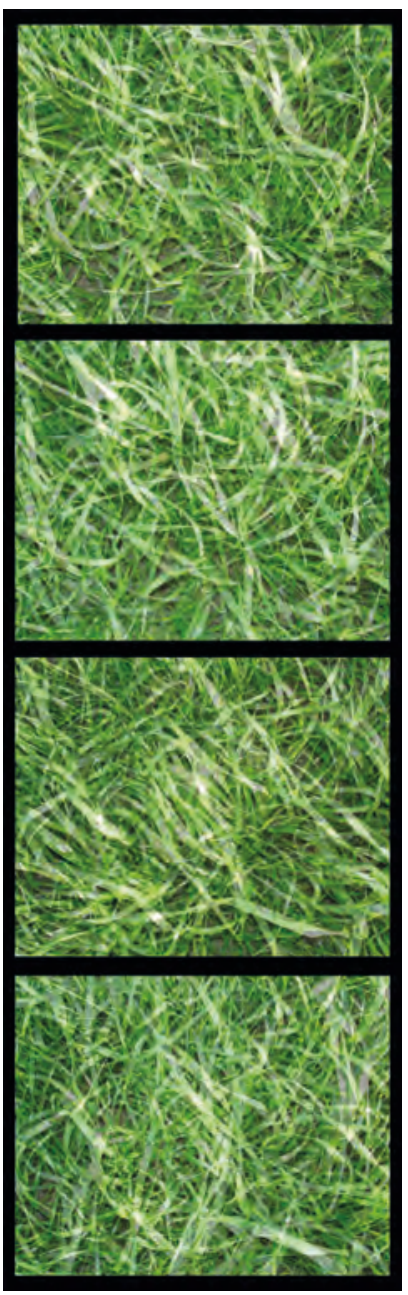




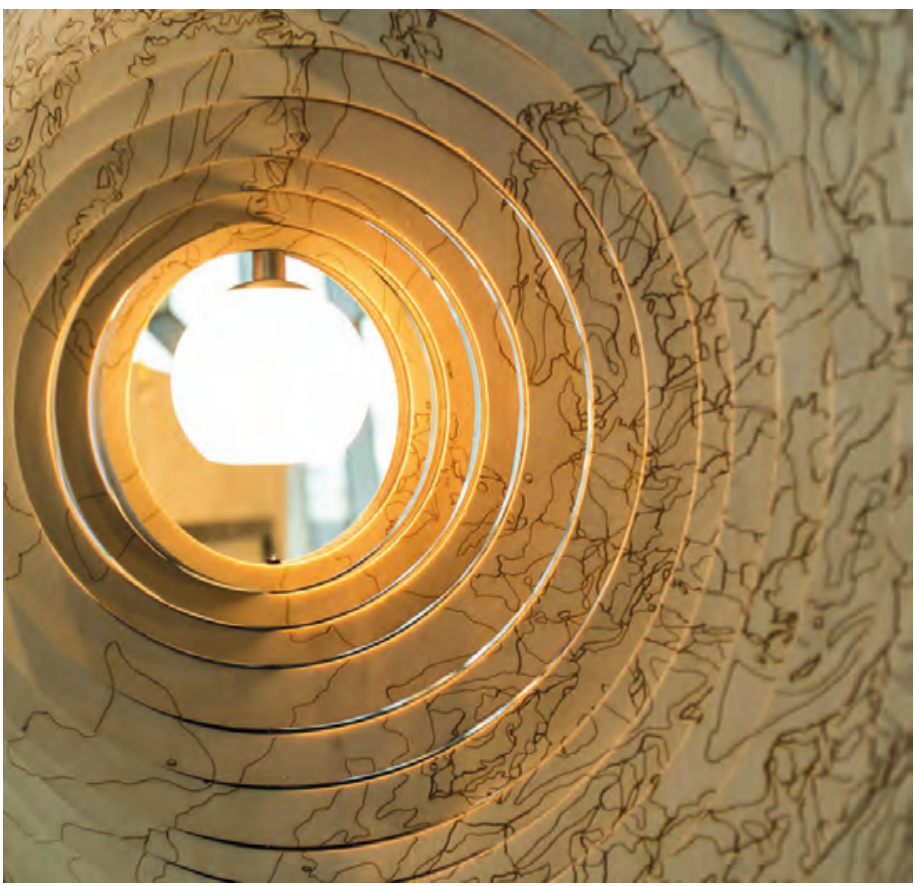

\title{
Heimsljós World Lights
}

\author{
MARÍA SJÖFN DUPUIS DAVÍĐSDÓTTIR
}

As an artist/designer my main ambition is aiming for holistic approach in search of sustainability in every used method. I relate my designs to nature as my belief is that we as a human beings are all part of the nature. I like to analyse those subjects according to my own logic and translate them into narrative structures of rich visual symbology within my creations.

When the objects we use every day and the surroundings we live in have become in themselves a work of art, then we shall be able to say that we have achieved a balanced life.

(Bruno Munari, Design as Art, 1966)

Birch cross wood

Mouth blown glass with Eco halogen light bulb. 


\title{
Rekstur Hearding 2009
}

\author{
SVANBORG MATTHÍASDÓTTIR
}

It is said that the Icelandic horse has, since in the time of the first settlers, been Icelanders most useful servant. In particular as means of transportation. In the last decade, increasingly, people are drawn to the experience of travelling on horseback. Preferably, travels into the wilderness, where a group of riders drive huge numbers of loose horses between places. The purpose is traveling and training. This requires both skills and knowledge on part of the riders but at the same time leaves them with an exhilarating experience of freedom. This is what these works are about; this Icelandic tradition of the heard and the horseman traveling freely through open country.

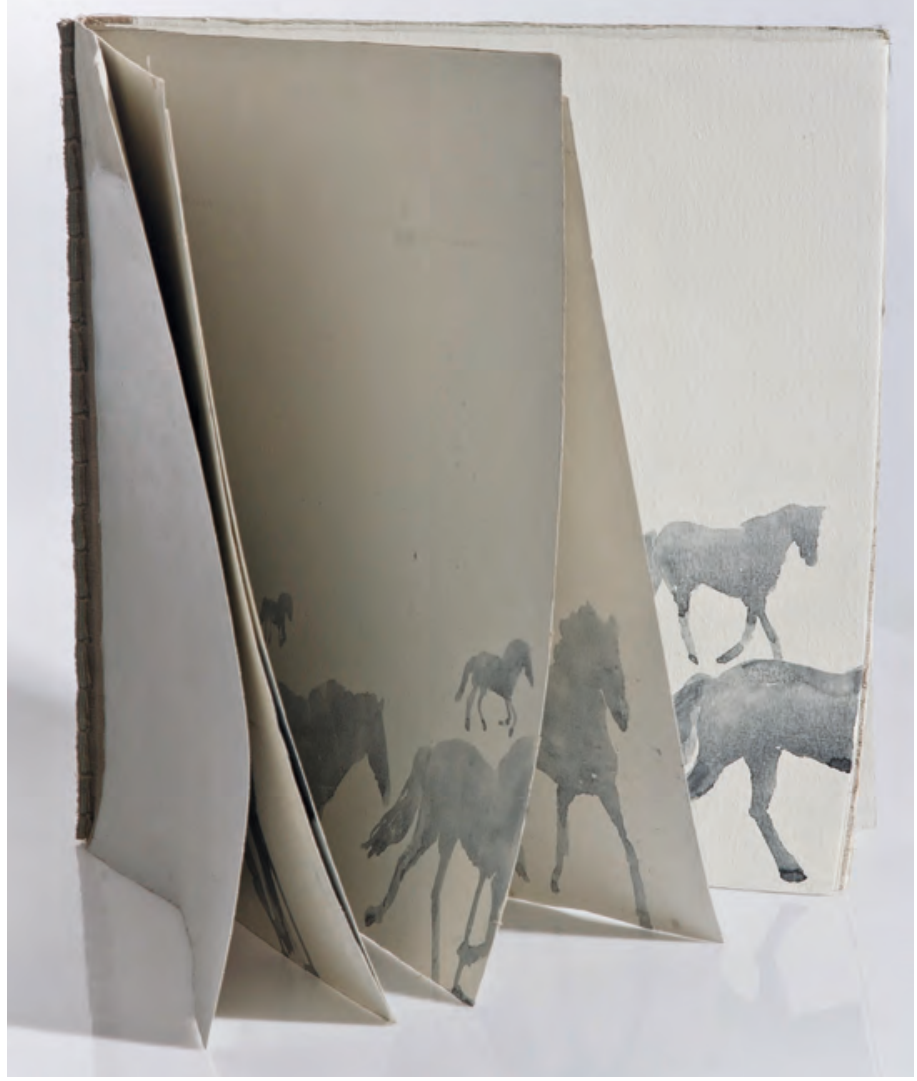




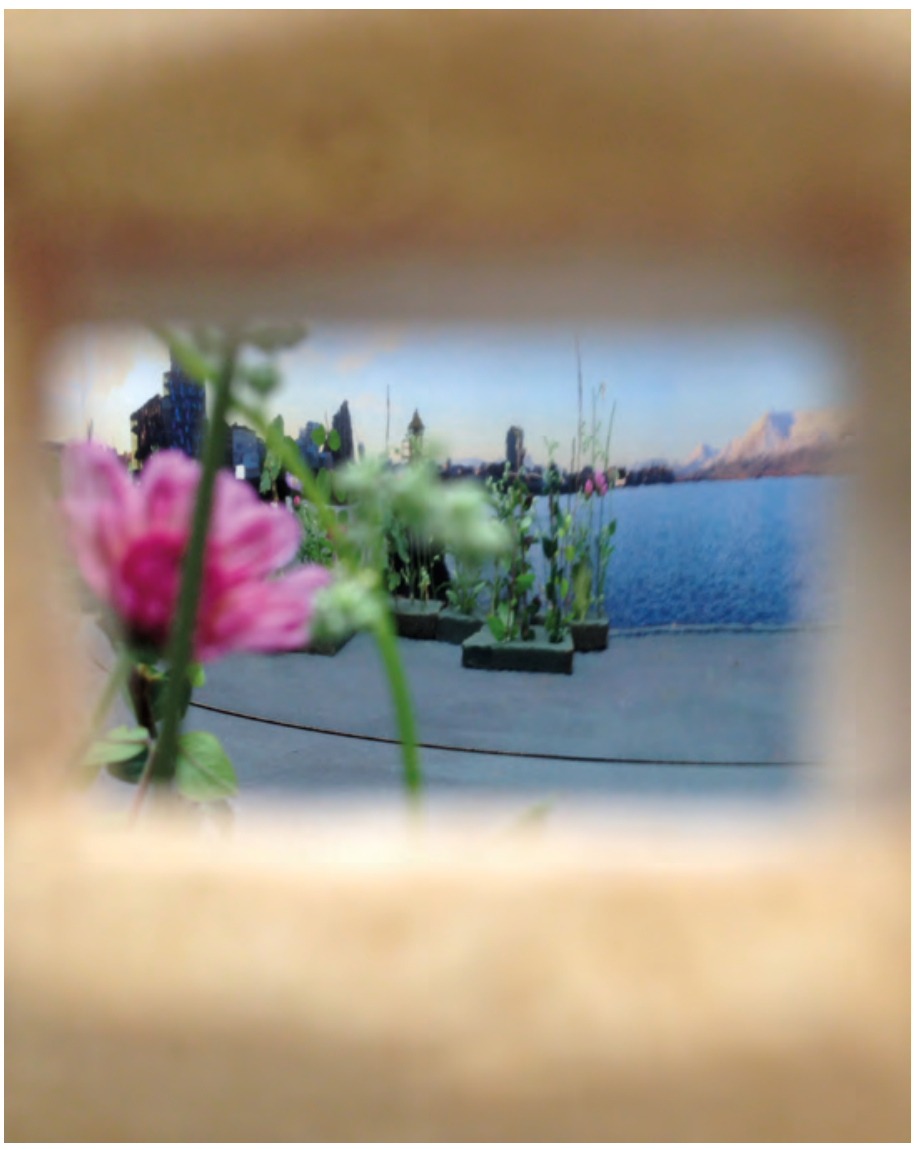

\section{Silent Spring; homage to Rachel Carson} RÓSA GÍSLADÓTTIR

'Silent Spring' (2013) is a homage to the biologist and writer Rachel Carson, who is considered one of the most remarkable women of the 20th century. Her book 'Silent Spring', published in 1962, was a landmark in the history of environmental protection. The main claim of this extremely influential book is that uncontrolled use of pesticides like DDT not only had detrimental effects on insects and bugs but also on birds and humans.

In 'Silent Spring; homage a Rachel Carson' the future is reflected in the present, while everything in the present borrowed from the future is the debt of the next generations. Pupils from Hagaskóli will help creating this work. 


\section{.. so on Earth}

\section{GUĐLAUGUR VALGARĐSSON}

Sustainability is all about paying it forward, passing it on, making the world as good a place or even better for our future generations. That means not only our world as a physical place, but also the more intangible idea and concept of our culture.

In that context, sustainability is also about looking back and deciding what we pass on from our time and times gone before us. Just as earth is made up of layers that we can examine and learn from, our history is made up of layers upon layers of people. Both as individuals and as a whole, their lives with all their knowledge, ideas, actions and memories combine to a whole that defines who we are today.

This is what we pass on.

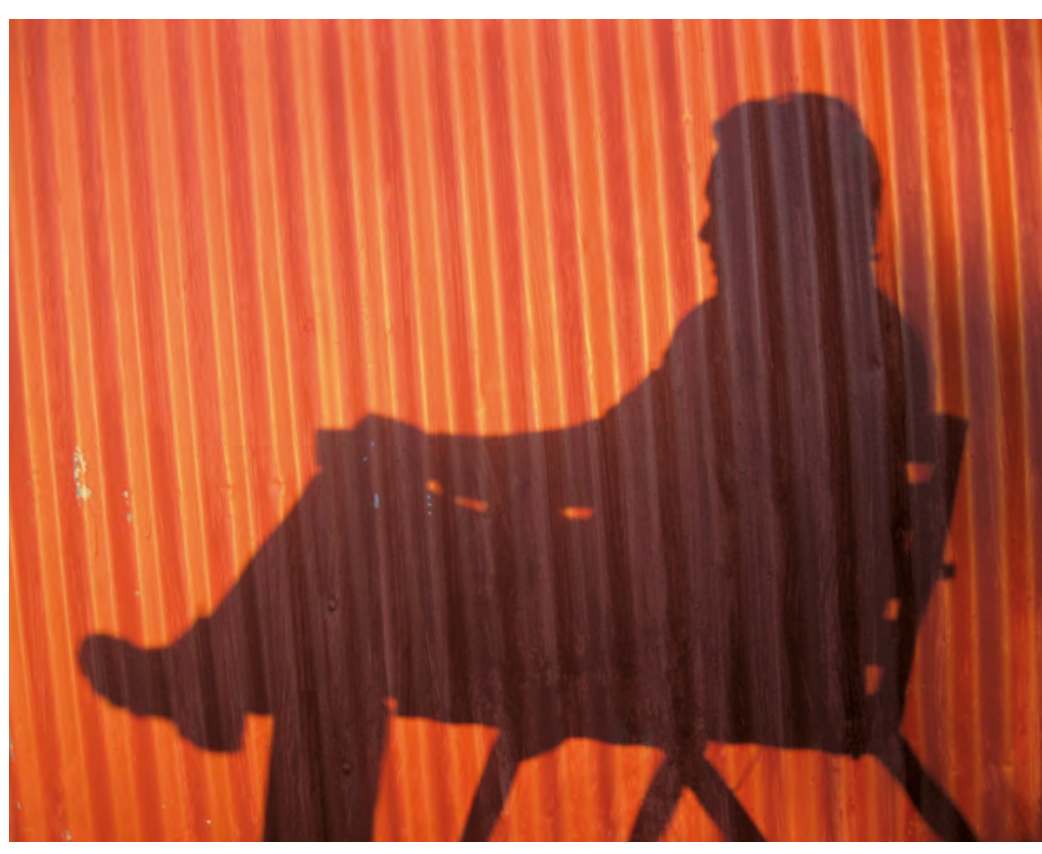




\section{Conversations}

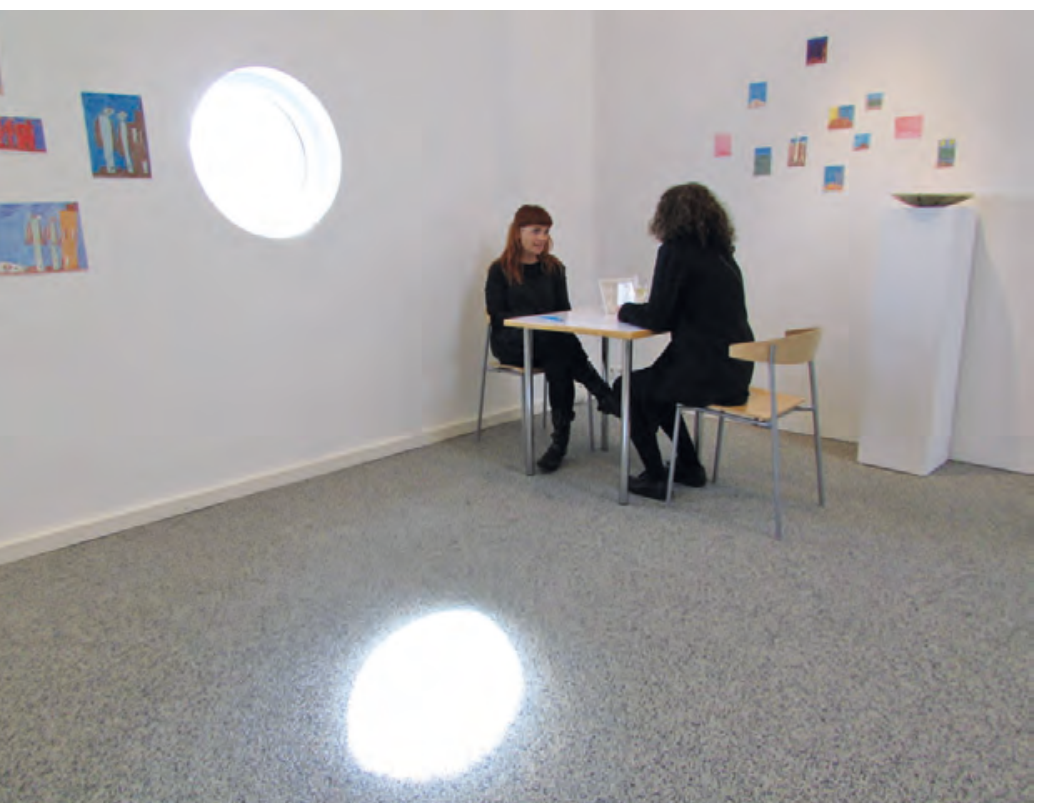

\section{LOVÍSA SIGURĐARDÓTTIR}

"Break the ice and ask me what the time is and we can have a conversation about the exhibition".

The main aim of this performance is to give the viewer an opportunity to go into his/her on flow and to discover and give meanings to the artworks by creating required space and by giving time to reflect on and heed to the works presented.

Conversations about unique work or exhibition can be based on imagination, intuition, feelings or logical factors. In a conversation we can train our critical thinking and present our independent review of this and that, not least our own society and environment

Performance - Conversation 


\section{Past Times Today}

\section{BRYNJA EMILSDÓTTIR}

I have specialized in textiles and kids clothing, always respecting the past and what we have left behind, giving a new life to what I find. My designs include clothing and decorative items, focusing on organic and recycled textiles, as well as local fabrics like the Icelandic wool.

'Past times today' represents how I give old fabric such as bed sheets, linen and old curtains new romantic life, making unique pieces with love.

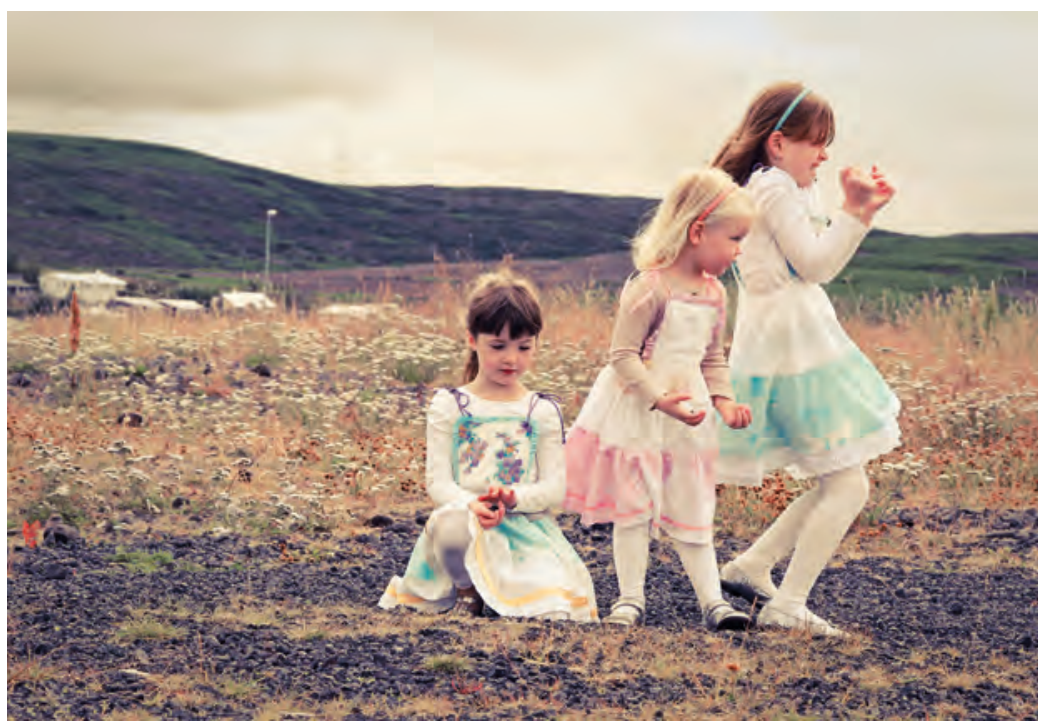




\title{
Suolla \\ On a Swamp
}

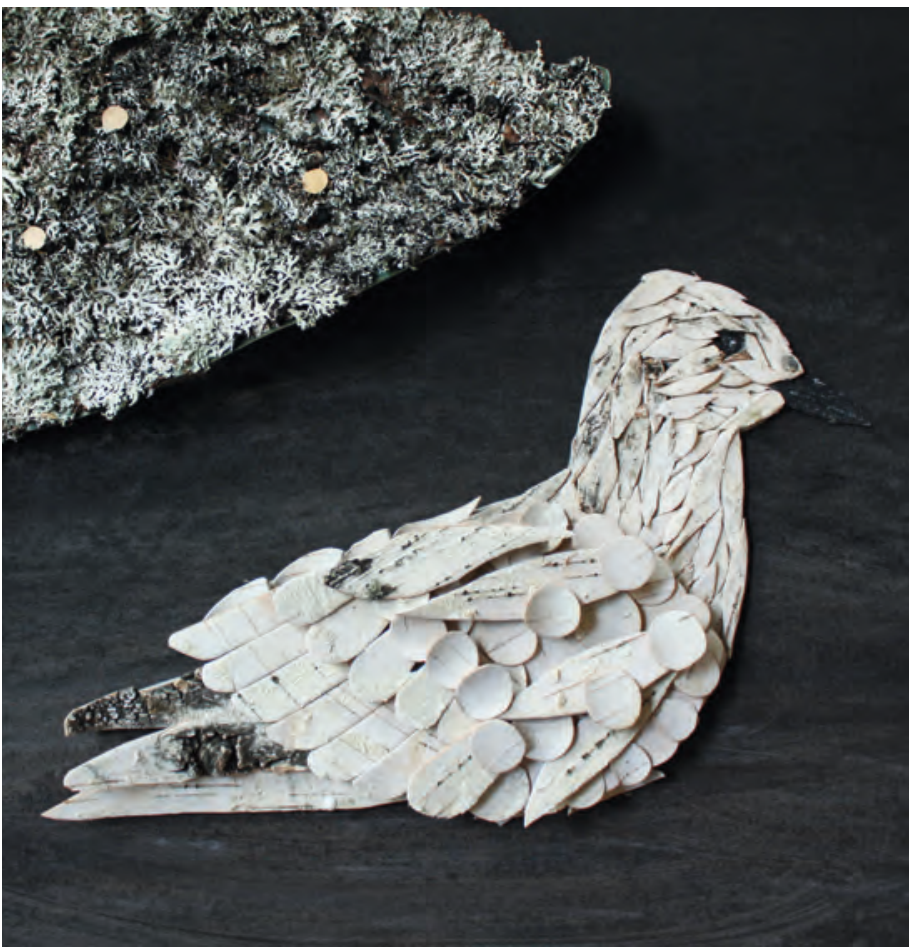

\author{
MARJO PERNU
}

'Suolla - On a Swamp' is an exploration of the use of natural materials like birch bark and lichen in the picture-making. Both materials are representatives from my home region, the coast of Bothnian Bay in Northern Finland. Both are also materials often invisible in a sense truism - local people see birches everyday without really paying attention to what they are seeing.

The white birch bark creates a beautiful texture and so do the different kind of lichens growing on it. On birch trees the lichens are usually green but lichens on aspens are, in turn, often orange. When looking from faraway the birch looks white but with closer look it might reveal its pearl white complexion. Moreover, if you look inside the tree, you may find even a more beautiful secret.. 


\title{
Fragments of a journey to Russian North
}

\author{
TIMO JOKELA \& MIRJA HILTUNEN
}

Our artwork in the exhibition is based on experiences from a Finnish-Russian art workshop held in Syktyvkar, Komi republic, Russia in April 2013. Jokela's snow installations in the landscape of the Sytola river are in dialogue with the Finnish-Russian student's documents in city center where local people took part in their performance. In both processes the traditional Komi patterns were explored through place-specific art.

Travelling to such a distant northern place was an essential part of the workshop and it offered space for sensitive cultural encounters. Roles and meanings from the "outside" world were dimming, only simple needs and the basics of everyday life mattered. In her video, Hiltunen focuses on one intensive moment during the long train trip between Finland to Komi.
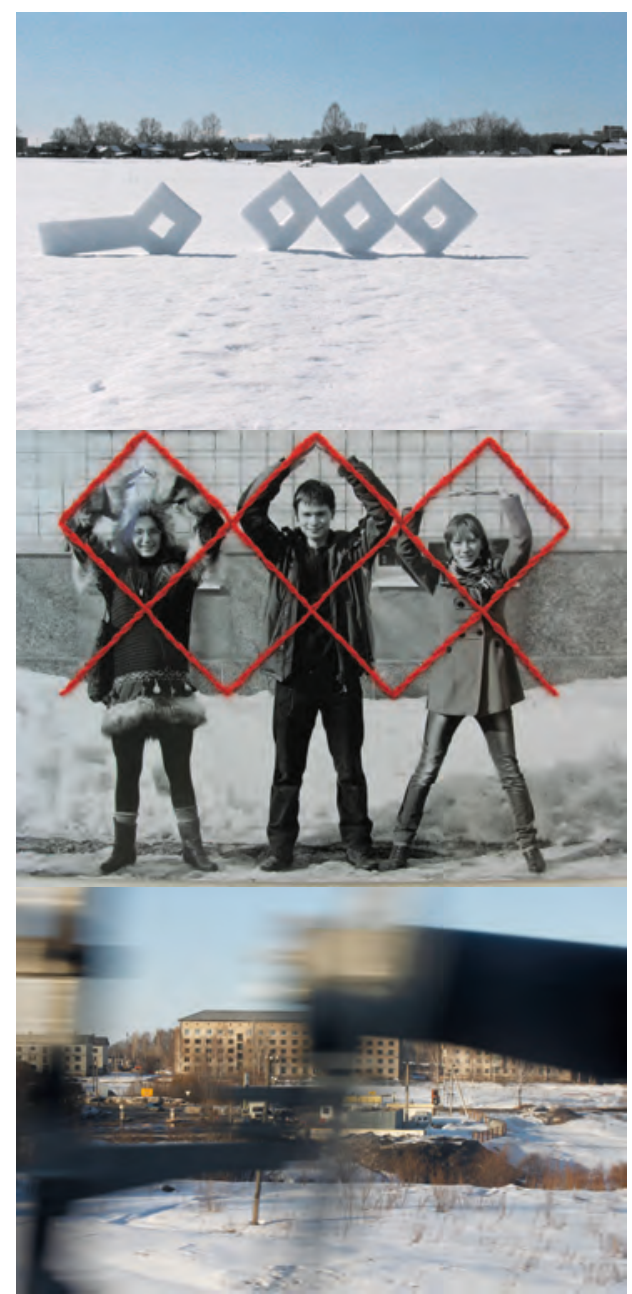


\section{Arctic Shore Lights}

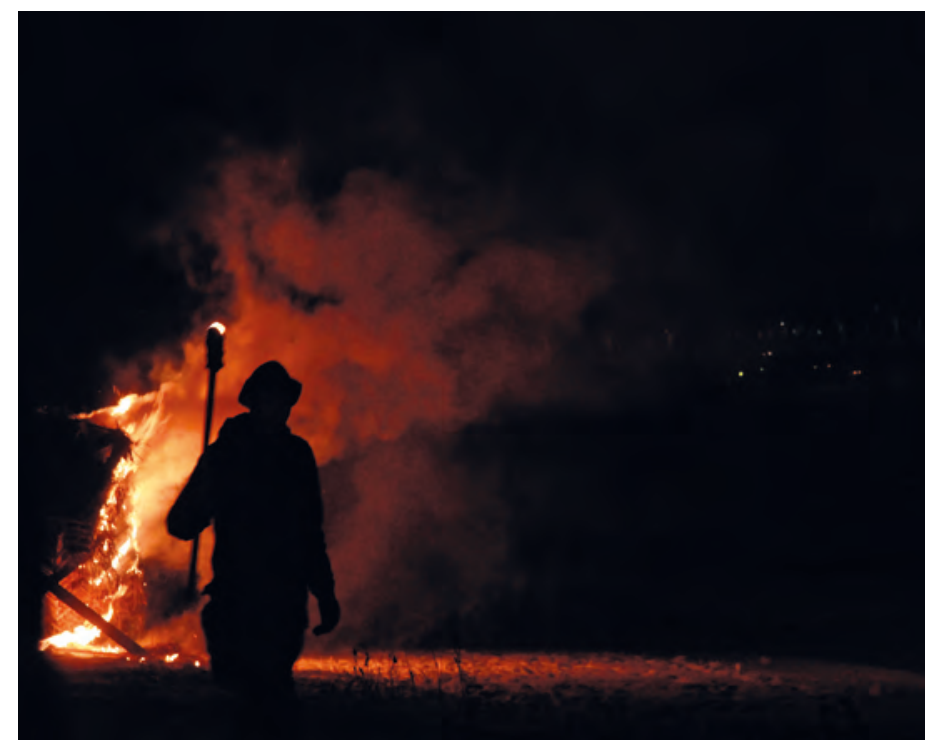

HILKKA KEMPPI \& SUVI AUTIO

Identity build with fire? Fire as a starting point for cultural exploration.

Northern Shore Lights consists of the documentation of two fire events; Shore lights is place-specifically build event in Reykjavik and it's inspiration annual River Lights event held in Rovaniemi, Finland. Shore lights fire art happening is organized by the University of Lapland, Faculty of Art and Design and the Iceland Academy of Arts.

These events celebrate the light as it begins it's journey through the polar night typical to these latitudes. The process that led to the event involved multidisciplinary ways of making art. Our artistic vision is to keep this event spreading, so that in two years there will be four of these events held simultaneously across the arctic. 


\section{Arctixperiences}

\section{ESTHER DORSMAN}

'Artixperience' presents several snow and ice art projects that I created, managed and carried out during the winters of 2010-2013 in Finnish Lapland. The projects are called the Levi Lounge, Surprises, the Snow Chapel and the Pello Snowpark.

The photo series visualize how the snow projects were established in collaboration with communities, university and local businesses. The designs relate to Arctic themes. They are considered as aesthetical and contemporary snow and ice art developments in the North.

Pello Snowpark features a community playground as a winter park. Surprises show my various smaller works. Snow Chapel shows the design of a snow chapel. Levi Lounge shows attractive interior creations for a snow hotel with snow terraces, caves and an innovative star heaven.

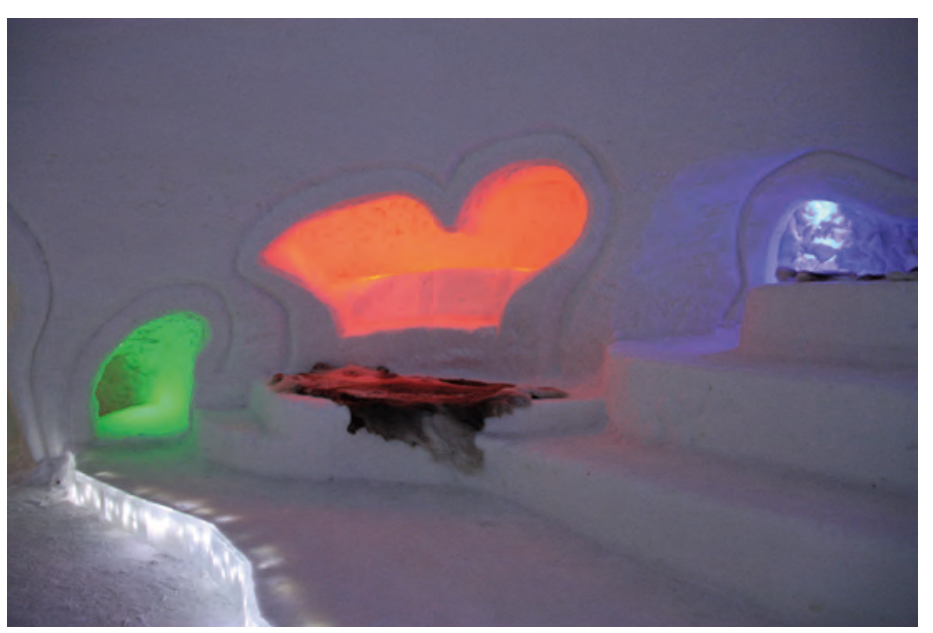




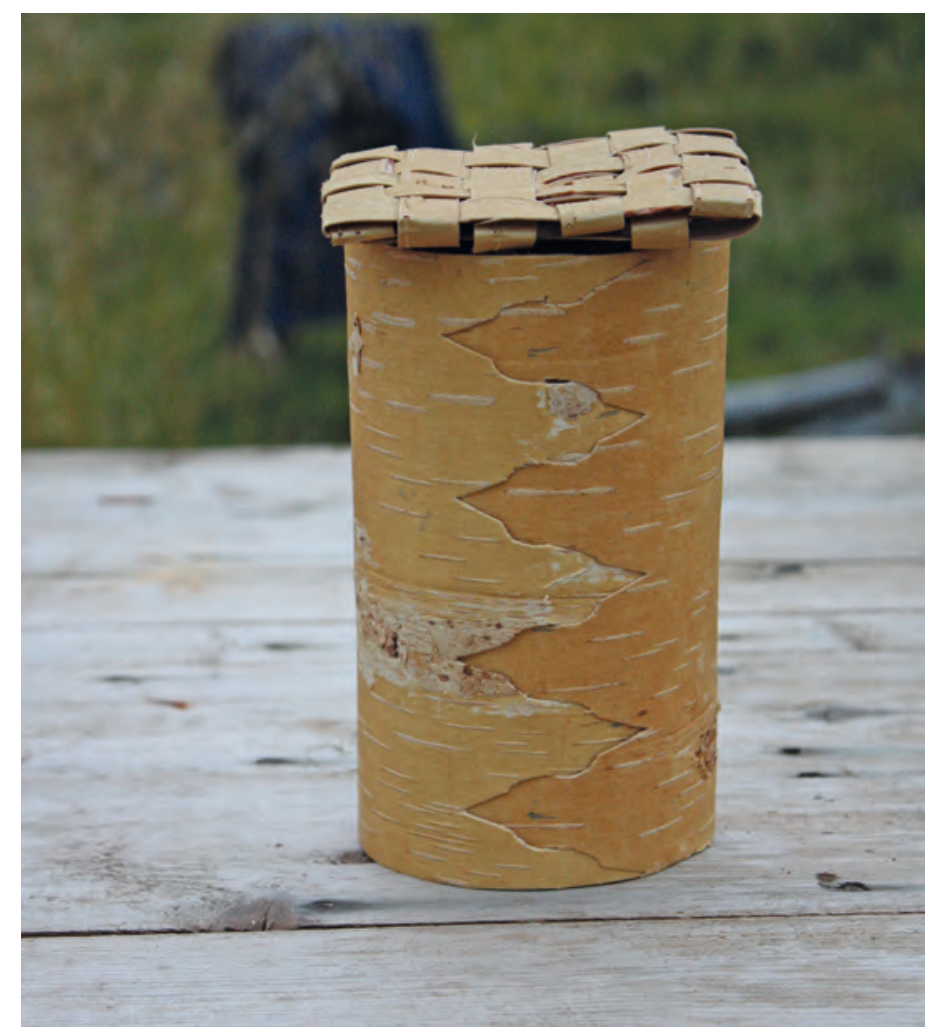

\section{'Never'-Land: Old Traces, New Spaces}

\section{METTE GÅRDVIK, KARIN STOLL \& WENCHE SØRMO}

Birch was the first species of tree to spread inland as the glaciers withdrew and is without a doubt the tree we consider to be the most Nordic. The use of 'never'(birch bark) has a long tradition stretching back to prehistoric times. The material was used as, for example, flooring, roofing and as storage containers.

Inspired by the locality Neverlia, a disused farm near Nesna University College, a project titled 'Never'-Land was executed in the late summer of 2013. This project is a cooperation between the Arts and Crafts and Natural Science departments and has the goal of showing students of education how to use birch bark as a traditional material in a modern context.

The 'Never'-Land installation shows the students journey back to our cultural offspring, Neverlia. Photographs, tools and works by the students will be presented from Neverlia showing bark as a sustainable resource.

'Never' in Norwegian = birch bark, Documentary photos, birch forest wall paper 


\section{Yesterday,Today, Tomorrow?}

\section{ANNE-KARI STEIRO BERG-HANSSEN}

I come from a beautiful archipelago lying in one of Northern Europe's most shallow ocean areas. We have a long lineage of people who have survived on the renewable resource offered by the ocean. Ca. 150 nautical miles North of this paradise lies Lofoten, a spawning ground for several fish species found in the Northern and Barents Sea. In no other place in the world is such a small area so important for spawning. Therefore, an oil catastrophe here would have bigger consequences than other places.

Lying offshore close to my island are five large oil platforms pumping thousands of liters of oil daily. Several politicians want to expand boring northward into Lofoton.

With this exhibition I hope to shed light on this problem and show that we all can take a standpoint and strive for the future we desire.

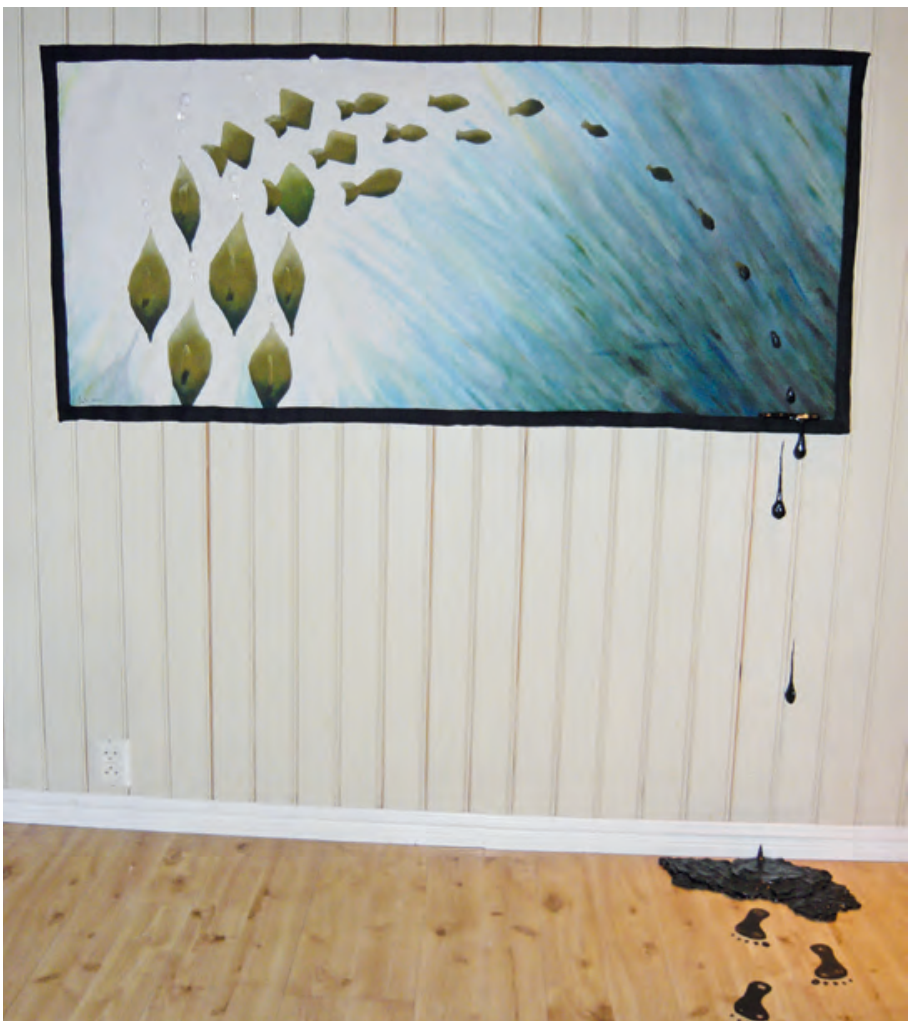




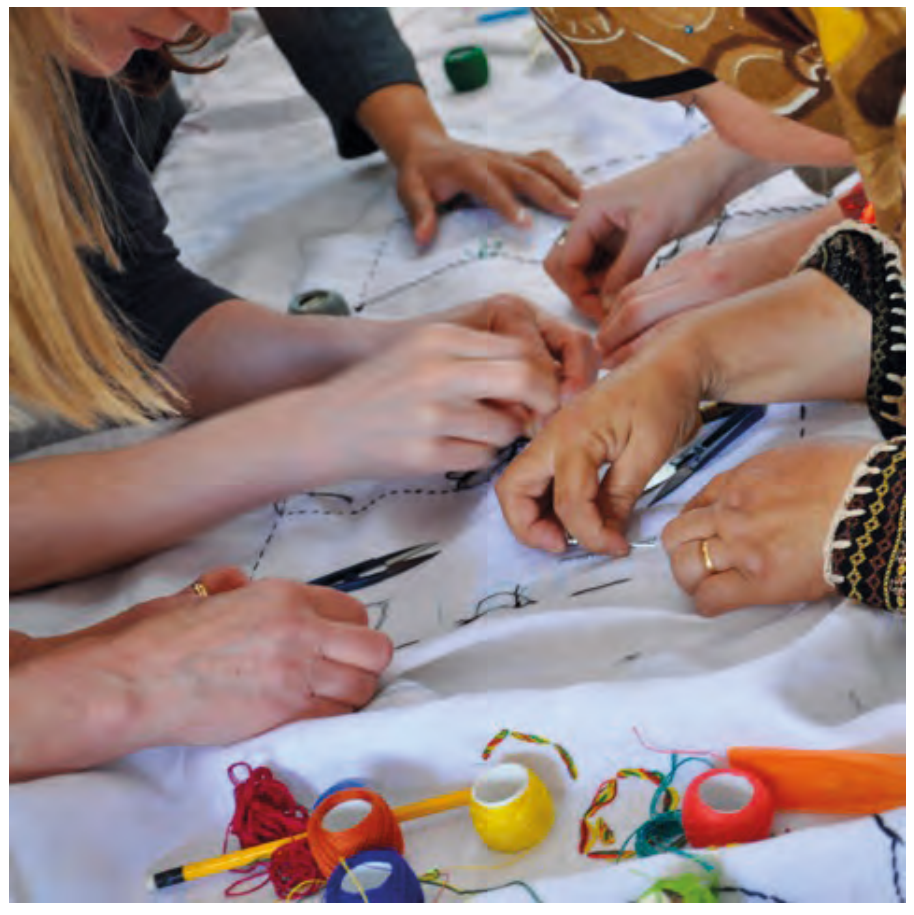

\title{
The Stitch Project 2011-2016
}

\author{
HILDE HAUAN JOHNSEN
}

We have extensive living textile tradition in the Nordic countries; we have learned these skills directly from our mothers and grandmothers. It is an unbroken chain of skills within textile tradition that we want to strengthen with sharing this knowledge with others. Textile is a social metaphor. We use the textile practice as a door opener for dialogue in many different settings. The project is intended as a meeting place filled with dialogue, stories, knowledge. and inspiration.

We have met people from Gaza, Tromsø, Jersualem, Bergen, Ramallah, Dale, Rantis, Kåfjord, and Oslo to learn about local area, traditions, political, social and cultural issues that occupy people, both in a positive and challenging way. We have already experienced how working together opens up dialogue and discussions. Men and women, children and youngsters, people of all ages join in.

Tablecloth 


\section{Nostalgica Utopica Futura}

\section{SOL MOREN}

This collaborative sound-video art project 'Nostalgica Utopica Futura' (inspired by Italian minimalist musical composer Luigi Nono) has one of the narratives of inspiration in historical, utopic ideal society built up in 1895 on an island called Norrbyskär, located at the coast close to Umeå. The island was totally (re)constructed, probably inspired by contemporary ideas about utopic societies, like the Morris novel, where the workers were 'taken care of' in all social aspects. The children in the video, Ivan Morén and Linnea Thors are ancestors of a family who lived at Norrbyskär during this period. Film production took place in the family house, called the Tailor House, where tales of the family were mixed with contemporary tales, to a gothic story of the drowned children (the script were written in collaboration with the children). The image style was influenced by the Nordic fine de siècle New Romanticism, with Swedish artist like Carl Larssons 'A day of celebration' and Axel Fridells 'Mr Simmons' or the 'The dying dandy' by Nils von Dardel. Sound was composed by J.M. Holmberg.

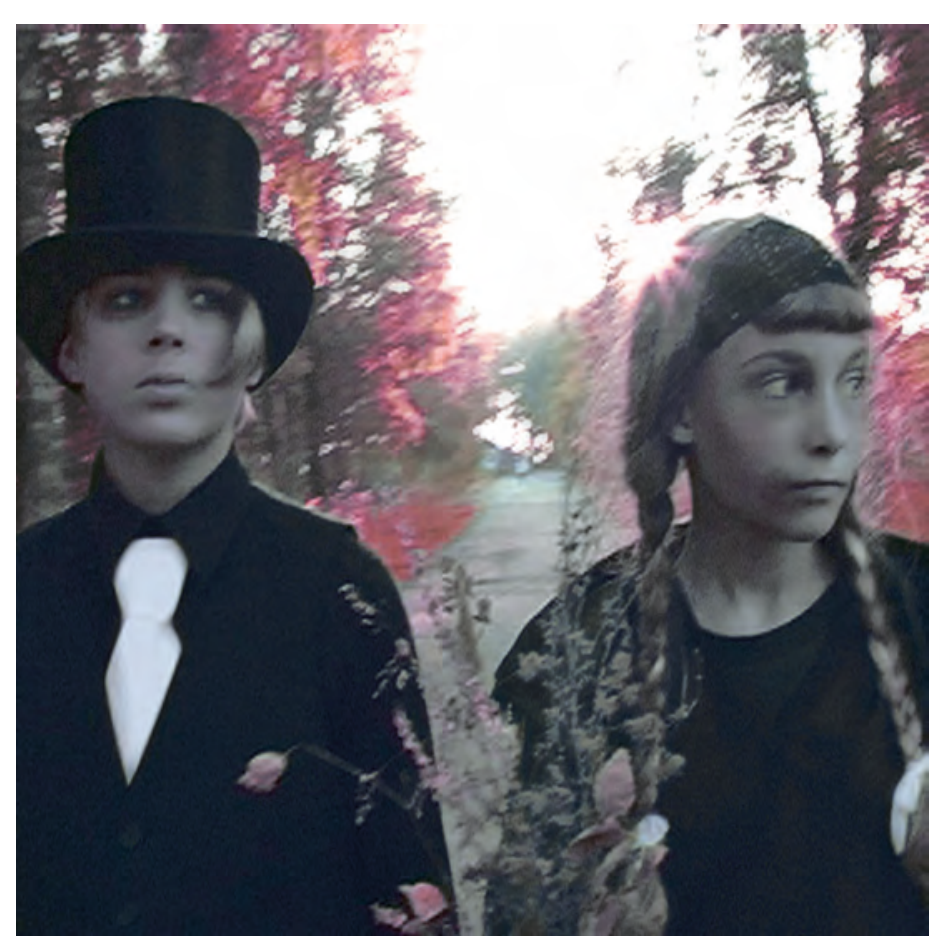




\section{Trading Routes: Grease Trails Oil Pipelines}

RUTH BEER

These photographs, video projection and sculpture are part of 'Trading Routes: Grease Trails, Oil Futures', a federally-funded project. They are intended to suggest poetic possibilities and also question the cultural and economic ecologies of land use, heritage and the imaginary of Canada's north as an empty wilderness. While challenging geographical terrain of the Canadian northwest and arctic landscape has supported Aboriginal and non-Aboriginal trade and transport of natural resources, now proposed pipelines for moving crude oil overland to coastal shipping overlap culturally important Aboriginal fish oil (grease) trading routes and pose opportunities and devastating social and environmental risks. The artwork addresses the complexity of this contested space. The inter-cultural project brings together rural and urban artists for dialogue, exchange and the production of artworks and exhibitions highlighting land-based knowledge promoting awareness of these issues related to national identity, the economy and the environment that also have global implications.

Installation: Photographs, Sculpture and Animation 


\section{A Third And Final Part: Peary \& Ahnighito}

\section{KATIE BETHUNE-LEAMEN}

A Third And Final Part: Peary \& Ahnighito is an existentially-tinged, looping re-imagining of the interactions between 19th century American Arctic explorer Robert Peary, and the Greenlandic meteorite known as Ahnighito, which Peary removed from its terrestrial home and brought to NYC. Peary is shown in a non-state, hovering over the ocean of Greenland's Davis Strait, intercut with close-ups of Ahnighito in a state of colourful, animistic presence. Peary's drive to be the first westerner to find the North Pole brought him again and again to Greenland, where he developed a tangential obsession with the socalled Cape York meteorites he would later seize. In this video, the relationship between object of desire-sought out, possessed-is now complicated, with Peary shown in a limbo-like state, while the meteorite glows with life. The video is comprised of backgrounds shot in Ilulissat, Greenland, green-screen live-action shot in Canada, and 3D CG animation.

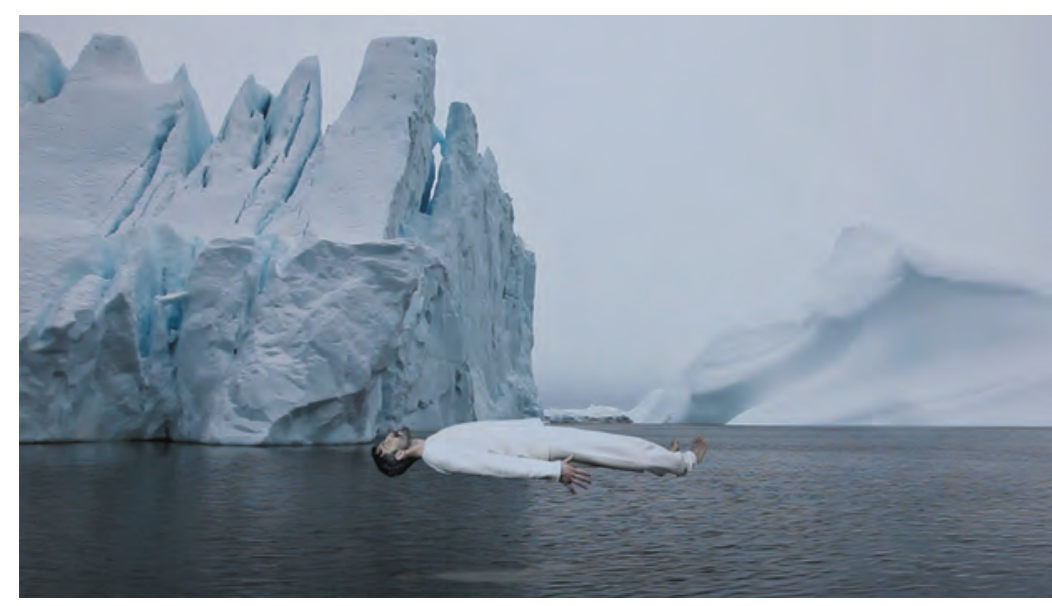




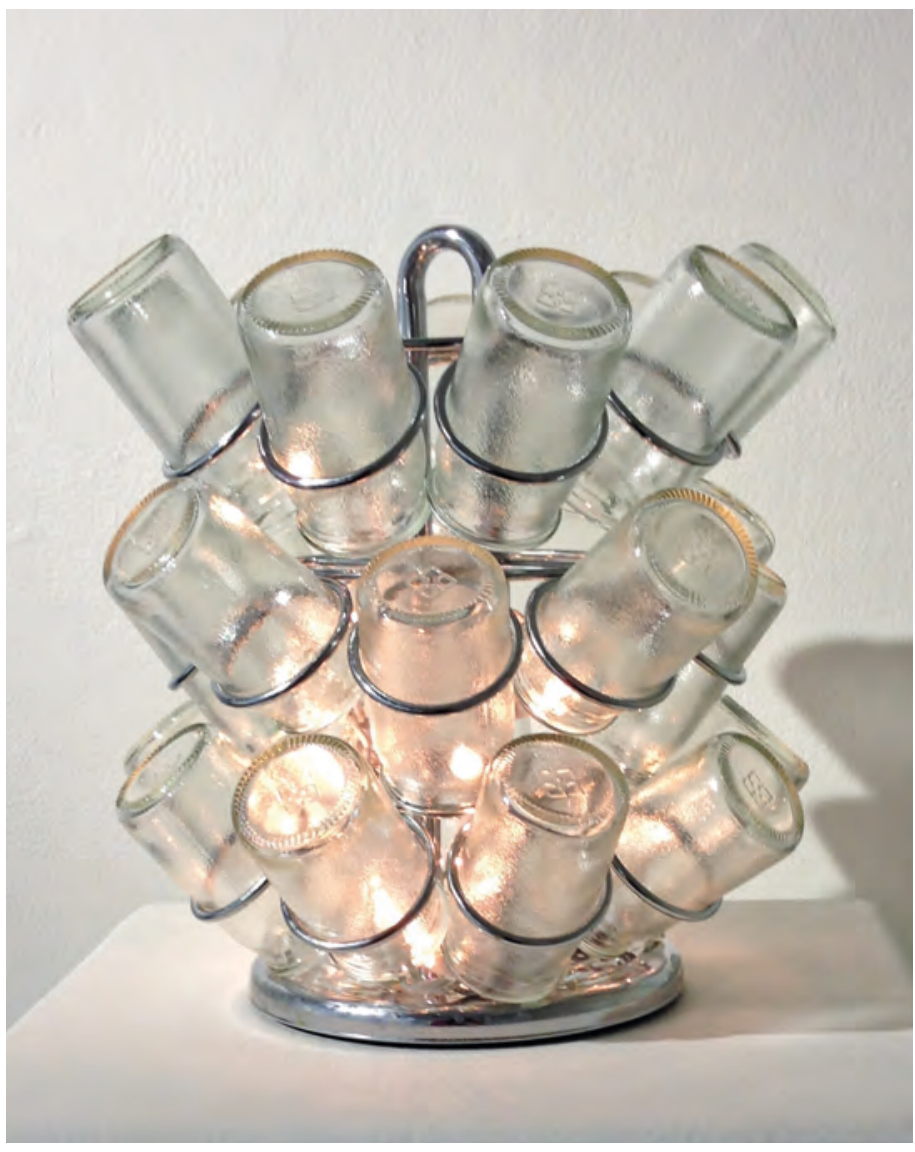

\title{
Junk to Funk Coffee Table Lamp
}

\author{
HERMINIA WEI-HSIN DIN
}

We cannot help but develop a socially responsible environmental art education curriculum in which values and aesthetic are combined in an instrumental manner for the benefit of all. - J. Ulbricht (1998)

The recent recycled-based art movement has offered a new perspective in looking at waste materials - a way emphasizing that artistic element can be applied to creative process for all ages and raise awareness of our relationship to the environment. Rooted in the 'reduce' and 'reuse' ways of dealing with waste products in the North, this piece was created using recycled materials gathered from thrift shops, and consumed energy drink glass bottles. Following the concept of the Junk to Funk project created in 2008, this artwork uses recycled materials to create beautiful yet finished functional artwork. This piece hopes to inspire further interest to engage much needed recycling-based art education programs in northern communities. 


\section{Moses at Singeak}

\section{DAVID MOLLETT}

My research on James Kivetoruk Moses, an Inupiaq artist active in Nome in the 1950s and 60s brought me to Singeak at Cape Espenberg, a very remote part of Alaska. Moses lived on the now long uninhabited cape for nearly 50 years. I did some of my own work there, painting, drawing and taking photographs to try to come to know the place and life that he used as source for his elaborate drawn and painted works.

I present four small works with a reproduction of a key Kivetoruk work from Singeak to establish a relationship with contemporary art, especially field painting and the Eskimo graphic artists of the late 20th century. (Moses being the most important of them.)

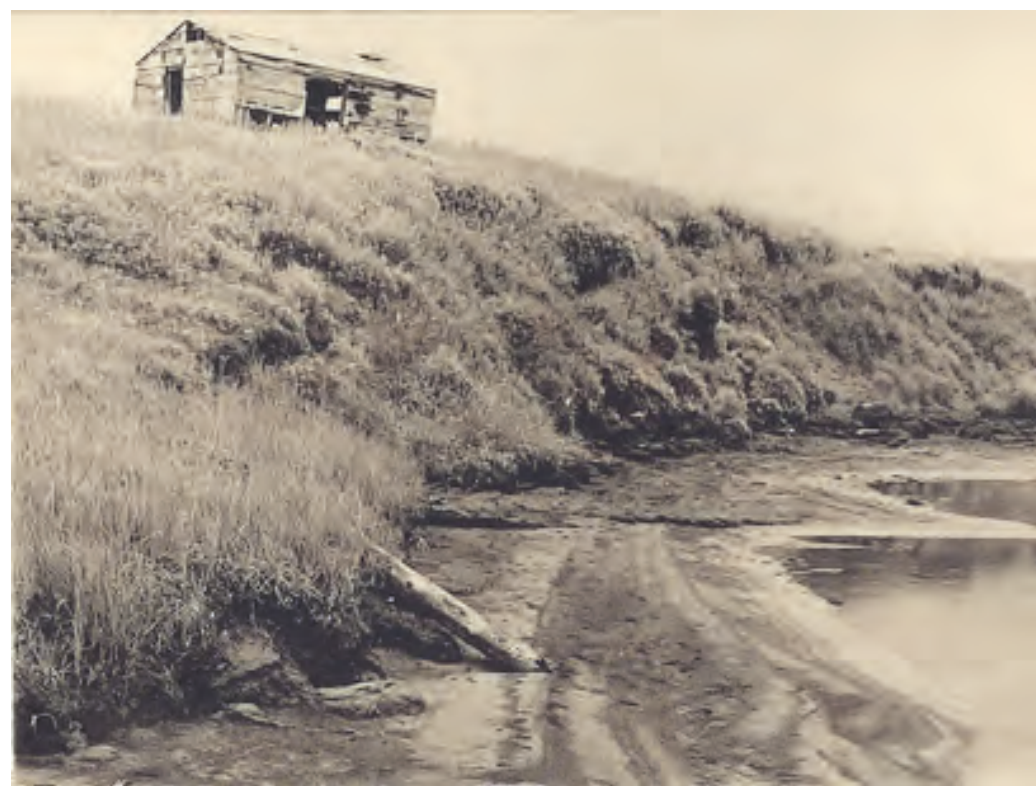



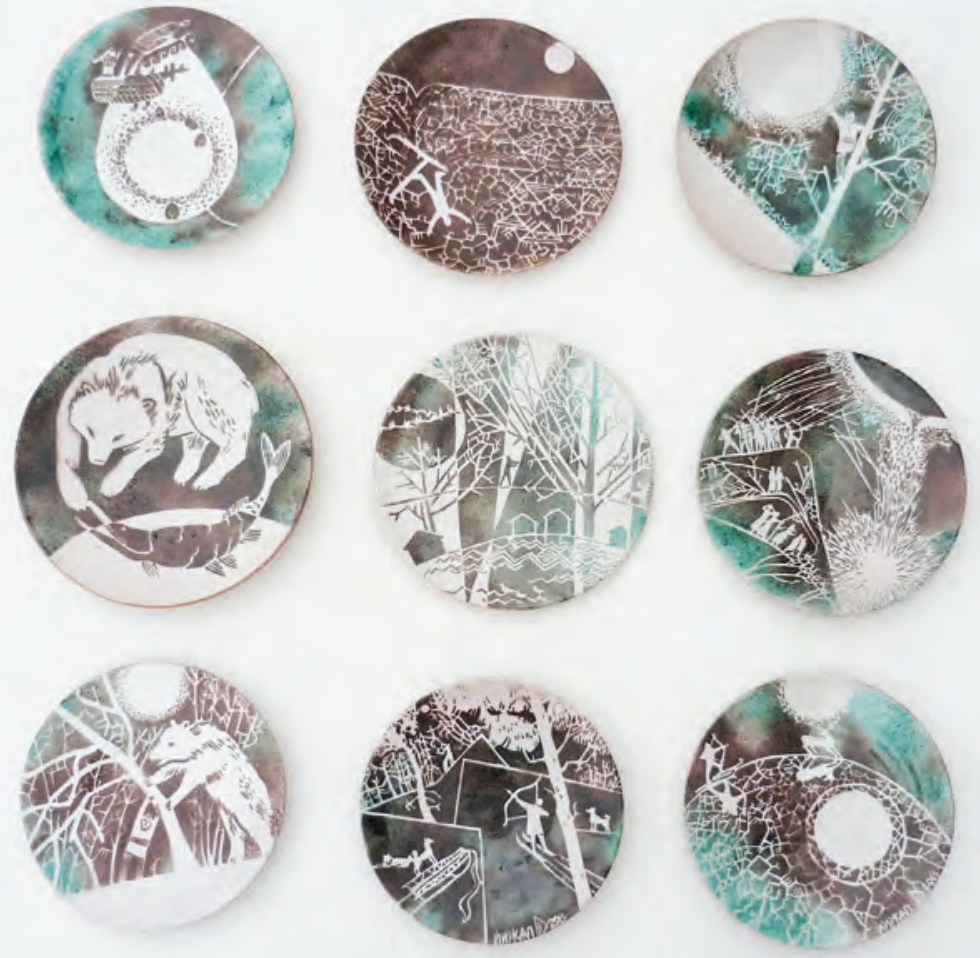

\section{Komi tales and mythological stories}

\author{
VLADIMIR DURNEV
}

Preservation and development of the cultural identity of the Komi is an important issue for the Komi Republic. I see my task to take part in the creating an aesthetically significant cultural environment which will attract interest of the citizens of Komi Republic to the indigenous culture due to the specific local art, which communicates in a modern visual language.

Technology of drawing images by the means of stencils and metal oxides (I am applying for a patent for this technology) allows creating a circulation of products in a small workshop. The first product in this technique is displayed in the permanent exhibition of the National Museum of Komi Republic. 


\section{Family}

\section{IRINA ZEMTSOVA}

These dolls are produced in accordance to the main methods, materials and technique of the Traditional Folk Dolls. The main idea of this set is to proclaim the traditional way of life of the North Peoples as a unique and protect the big-scale family as a symbol of the survival of the traditional rural culture in the modern world.

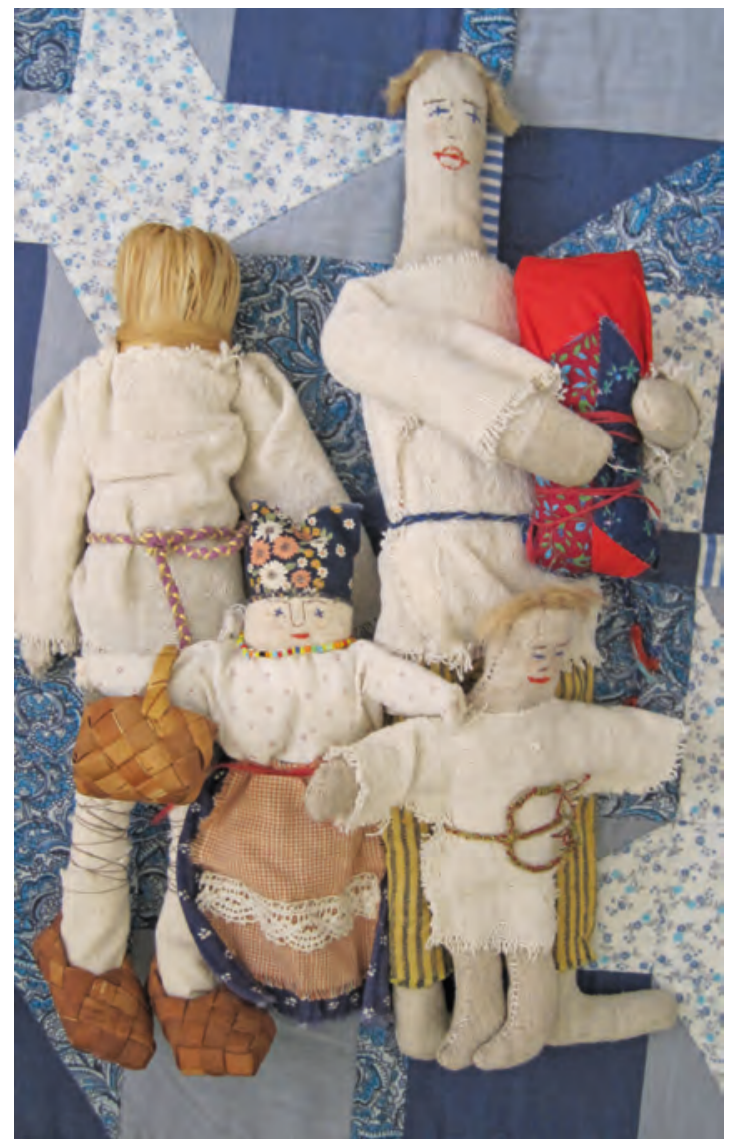

SYKTYVKAR STATE UNIVERSITY, KOMI REPUBLIC RUSSIA 


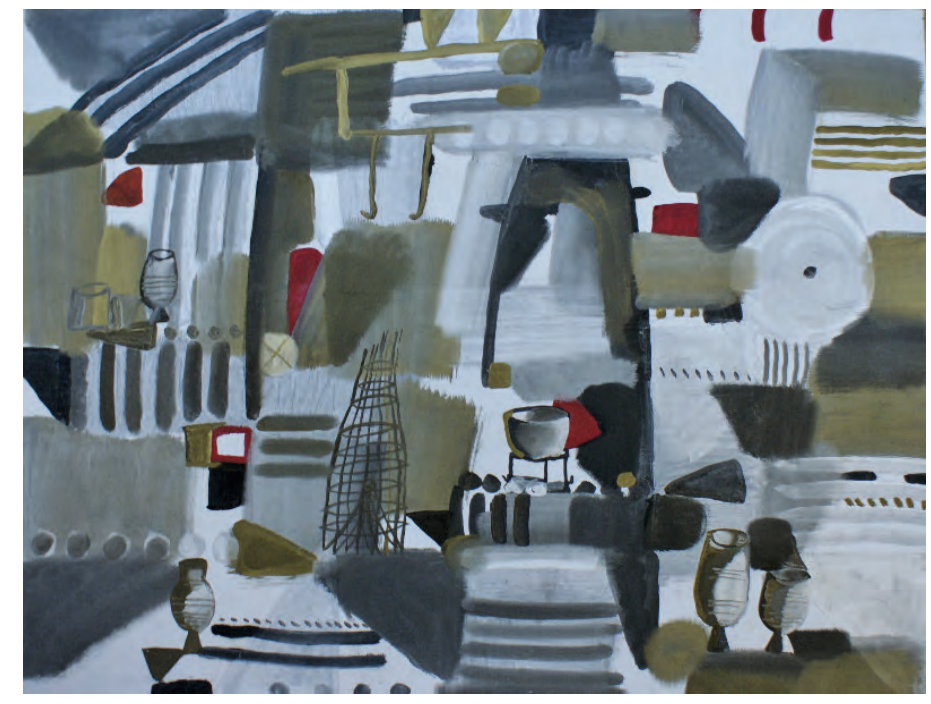

\title{
Fireplace
}

\author{
TUIAARA SHAPOSHNIKOVA
}

In my art works synthesis of decorative is combined with artistic beginnings. My styles are realism, ethnosymbolism and abstractionism.

I am a representative of indigenouse northern people Sakha. That is why the main themes of my works are faced with folklore traditions, ethnoculture of northern peoples. 


\section{Silent Illumination Sea Echoes}

\section{ALAN PATERSON}

Banners and mixed media works attempt to reveal some of the internal and external characteristics of the art making process as a place / space of visual inventions that encourages the artists felt sense of the interconnectedness of life - a meditational sense of oneness. Inspiration from the Zen symbol, enso, as a circle with an opening, connects into the artist's mindful practice with being in the moment. The images are concerned with selected encounters and interactions within the natural world in the North East of Scotland and responding to the physicality of lived life impacting on internal mind and body space. Within the context of transitions from external to internal or vice versa there is a greater need for listening to exchanges of meaning and feeling in relation to potential creative possibilities and processes that enable the artist to explore artistic language and subliminal sensitivities... the fringe material of the conscious and subconscious. The images symbolise a transitional passage into mind, emotions and contemplation.

Mixed media $1 \mathrm{~m}$ x $1 \mathrm{~m}$

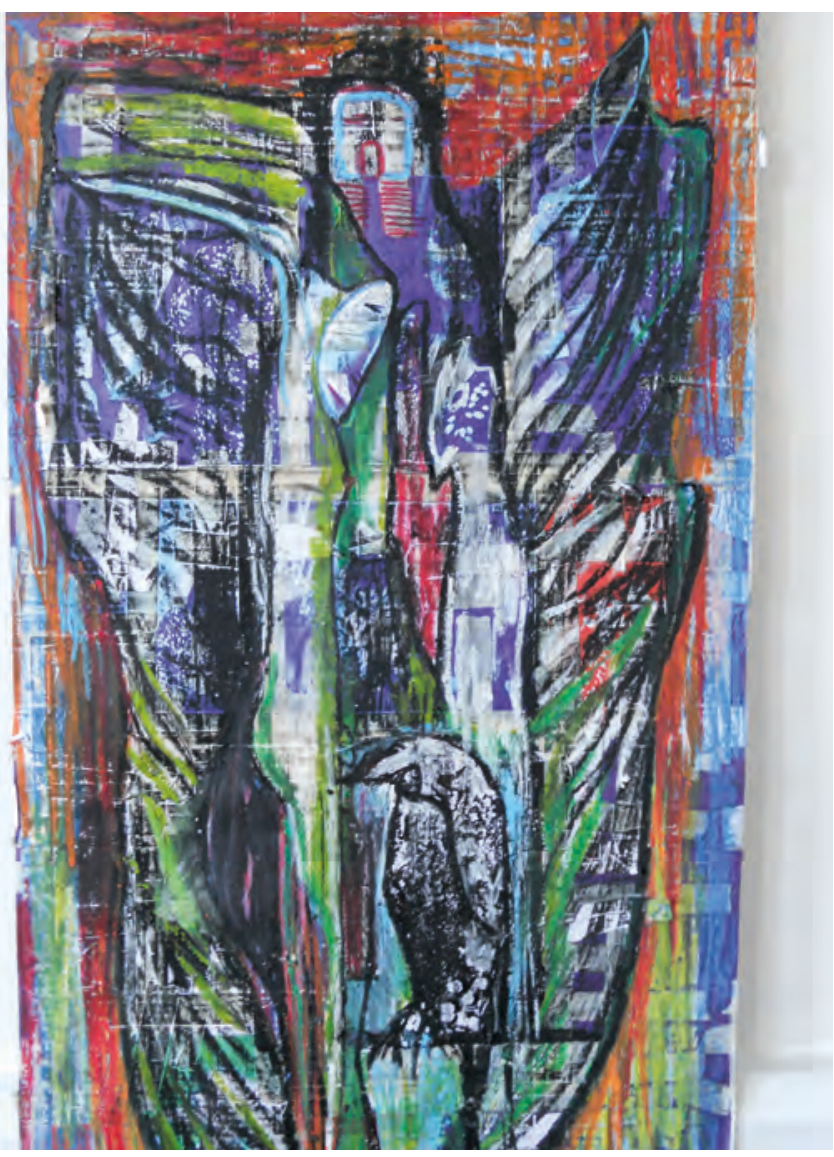




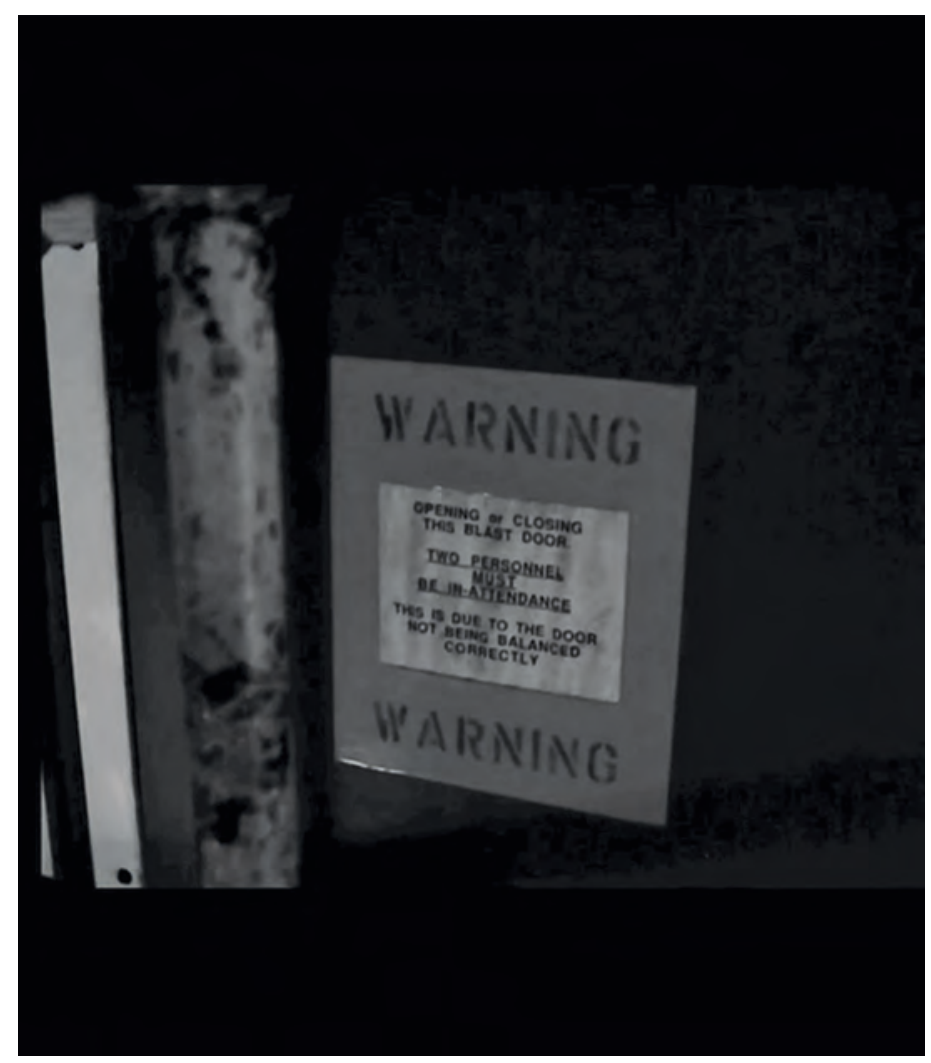

\title{
Countdown
}

\author{
ROXANNE PERMAR \& SUSAN TIMMINS
}

Countdown uses film and photography to explore the deserted operations block and bunker at Saxa Vord, the largest of the Royal Air Force installations in Shetland, which were once part of NATO's Early Warning Radar System. The term 'countdown' is a play on the British Government's much derided Cold War public alert system, the 'Four Minute Warning'.

Our recent work explores northern and Arctic issues with specific reference to the Cold War. We employ a range of artistic strategies to investigate the role these regions played in the Cold War as part of the radar network for NATO's line of defence against the perceived threat of nuclear attack from the former Soviet Union. Like other Northern communities, Shetland was strategically very important during the Cold War. There is evidence remaining throughout the islands of listening stations, bunkers and radar installations from this period.

Film 4 mins

Photography 18x 21.59 x $10.8 \mathrm{~cm}$ 


\section{Lossie Forest I, II}

\section{GINA WALL}

This exhibition brings to a tangible conclusion my current research activities which have investigated the idea of north in relation to Jacques Derrida's notion of hauntology and Tim Edensor's spectral urban landscapes. Derrida argues that the spectral is the very essence of photography and considered in these terms, photography is hauntology par excellence: a medium which bears witness to and carries the trace of the other. I conclude that the idea north is itself spectral, but in the most productive of senses.

My most recent photographic work has taken me to the forest landscapes of the Moray coast and the coastal fringes of the Orkney islands to look at the overlay areas of scenic beauty and the presence of the relics of war. These images will be published in Routledge's Visual Studies in November 2013 in a piece that I have written entitled 'Ghost writing: photographing the Spectral North'.

Black and white photographs

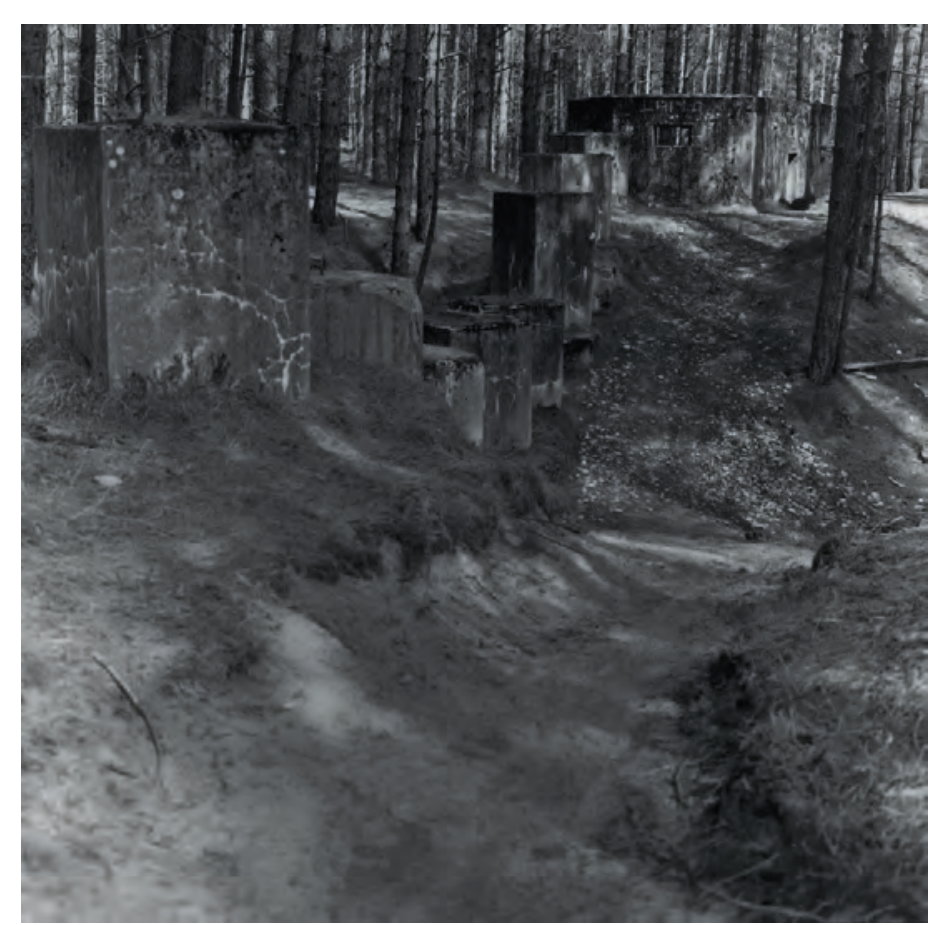




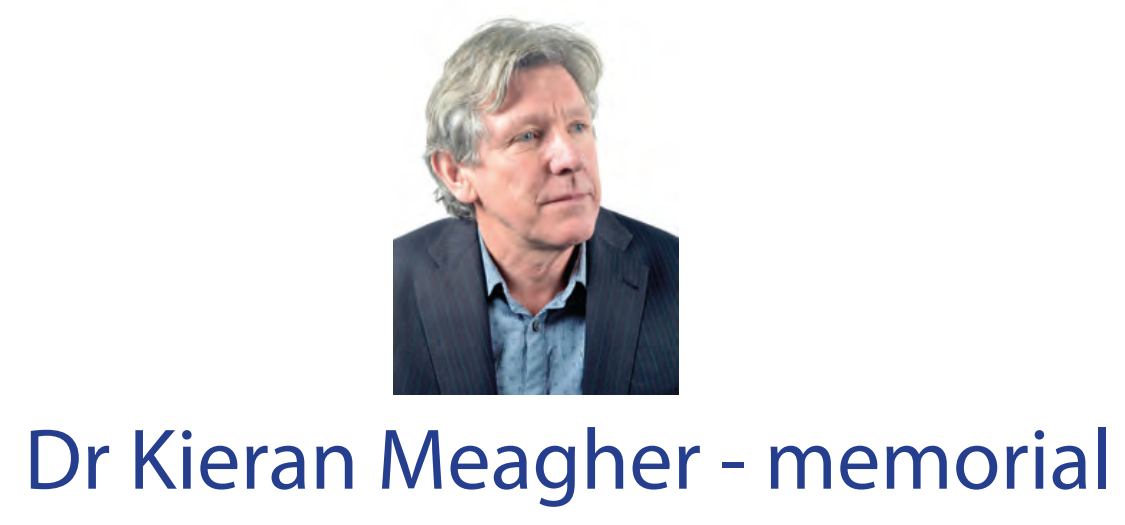

At a time when we celebrate the opening of the Relate North exhibition, we remember our colleague Dr Kieran Meagher, artist and educator from Ireland. An example of Kieran's work appears on page 7 of the catalogue together with his statement about the work he intended to produce for the exhibition. Sadly, it was not to be. Kieran passed away peacefully after a sudden, short, illness on 4 September 2013.

Those who knew him will remember his good humour, benevolence and creative spirit. Kieran brought his insightful and artistic outlook to his work in art and design teacher education and was respected by all who worked with him. He was working towards making paintings for this exhibition when he was taken ill in July 2013. It is with sincere thanks to his widow, Sheelagh, that we are able to include Kieran's work in the exhibition and catalogue.

Kieran worked at Limerick School of Art and Design on the
Atlantic coast of Ireland where he led art and design programmes in art and design teacher education and the online Masters-level degree in art and design education. He studied painting and printmaking at Limerick in the 1970s and holds M Phil and PhD degrees from the University of Liverpool. As an artist/researcher/ teacher, one of his main concerns was investigating how creative art practice informs the work of artist-educators. His most recent painting and photography practice focused on two main themes, the natural environment and vernacular architecture.

As we open this exhibition, we remember Kieran and celebrate his work.

Glen Coutts,

University of Lapland 



\section{Arctic Sustainable Arts and Design Network}

Arctic Sustainable Arts and Design (ASAD) is a Thematic Network (of University of the Arctic) that aims to identify and share contemporary and innovative practices in teaching, learning, research and knowledge exchange in the fields of arts, design and visual culture education. In summary, the network seeks to promote cooperation between academic institutions and communities; advance art education amongst members and share both traditional and contemporary practices in art, teaching, learning and research.

ASAD currently has 26 member institutions in 8 countries around the Arctic and Northern regions; the lead institution is the University of Lapland.
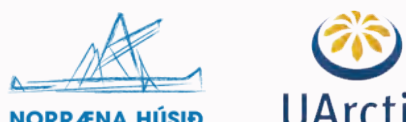